\section{International Journal of Research in Social Science and Humanities (IJRSS)}

DOI: http://doi.org/10.47505/IJRSS.2020.9112
E-ISSN : 2582-6220

Volume 1, Issue 3

Jul - Aug - 2020

\title{
Nigeria's Interventions in West African Conflicts and Regional Security
}

\author{
Dr. Joseph C. Ebegbulem \\ Department of Political Science \\ University of Calabar \\ Nigeria
}

\begin{abstract}
The achievement of regional security has been a cardinal foreign policy objective of Nigeria since her independence from Britain in 1960. Through the instrumentality of the Economic Community for West African States (ECOWAS), Nigeria has made immense contribution towards the achievement of this regional objective of promoting and maintaining regional security. Nigeria's contribution to regional security in Africa, especially the West African sub-region through mediation and interventions in conflicts has never been in doubt. In her effort to promote and maintain regional security, the country has been able to provide logistics and funding at very crucial moments in the history of ECOWAS. Through constant interventions in conflicts in West African sub-region, there is no doubt that Nigeria has been able to play a defining role in regional security in the sub-region. This paper discussed the position of Nigeria in West Africa, and her interventions in the sub-region. The paper also examined Nigeria's contribution to regional security and critically analyse her national interest and interventions in West Africa. Finally, the paper concludes that Nigeria has made immense contributions towards the promotion and maintenance of regional security, and has intervened in almost all the conflicts in West Africa without corresponding positive reward.
\end{abstract}

Keywords: Regional security, Leadership, Intervention, Inter-ethnic conflict, Foreign policy.

\subsection{Nigeria And The West African Sub Region}

Nigerian foreign policy towards West Africa is centered on the Economic Community of West African States (ECOWAS). Assisted by the windfall of the 1970s oil boom, Nigeria led the move for the -creation of ECOWAS in 1975. Over the years the' country has been the chief patron of ECOWAS, paying more than a third of the sub-regional organisation's budget as weir as prodding the various forms of assistance to its neighbours.

Within the West African sub-region, Nigeria has sought to manage inter-state relations under the framework of the ECOWAS and other bilateral arrangements with its neighbours. In this connection, it has made the promotion of peace and security the primary, consideration, based on the conviction that economic development and regional integration cannot be superimposed on an unstable region. It is Nigeria's strong conviction in ECOWAS that fully integrated West Africa, under democratic governments, with a common vision and shared prosperity, heavily dependent on one another for sustenance, is unlikely to fight one another. This is why the ECOWAS has developed the most advanced mechanisms and instruments in the spheres of regional integration and peace promotion. Apart from the success already recorded by the organisation in the promotion of free movement of persons-and goods, trade liberalisation (abolition of visa regimes, introduction of ECOWAS passport, etc) the regional organisation has put in place peace and security arrangements, notably ECQMOG, which was responsible for the restoration of peace and stability in Liberia, Sierra Leone, Guinea Bissau etc.

Nigeria has also deployed non-military, diplomatic means of assisting other West African countries in crises, which were capable of snow balling into serious internal strife, if not nipped in the bud. In Sao Tome and Principe for instance, it took the personal diplomacy of then Nigeria's president, Olusegun Obasanjo to reverse the military coup d'etat that took place in that country, which returned President Fradique de Menezes to power in 2003. Similar efforts were made in Togo, to ensure the return of constitutional rule, following the death of President Gnassingbe Eyedema.

Equally significant is the steady progress that was made in the peaceful resolution of the longstanding dispute between Nigeria and Cameroon over the Bakassi Peninsula, following the ICJ judgment of October 2002. Contrary to widely held fears, Nigeria and Cameroon did not go to war as both countries chose the path of peace in implementing the judgment. As earlier 
indicated, this commitment to peaceful resolution of disputes was one of the major reasons for the creation of the Economic Community of West African States (ECOWAS) in 1975. Besides securing its overall objectives of regional economic integration, ECOWAS served, by that measure, to reduce the reliance of other West African countries on Western foreign powers for economic and military assistance.

Another core issue of Nigeria's African policy looked at by authorities in Nigerian foreign policy is financial, material and economic assistance to needy West African states. Akinbola (2000) and Akindele (1998) consider the milestone in Nigeria's economic diplomacy, with details of Nigeria's loans, grants and donations to some states in West Africa. Studies carried out by these scholars also look up to the extension of Nigerian resources such as power and natural gas to West African states. A denominator of Nigeria's foreign policy making since the 1970s has been oil and gas. These positioned it to render assistance to needy West African states. Nigeria made oil and gas readily available to neighbouring West African states, while also providing steady electricity to some of them. This commitment to West Africa lies in the strong Pan-African bent of Nigeria's foreign policy. Works that have examined this African sentiment of Nigerian foreign policy include King (2005), Okon (1998) and Shaw (1987). Their studies found out that the spirit of Africa in general and West Africa in particular in Nigerian foreign policy culminated in the quest for integration, peace and development that berthed the Economic Community of West African States (ECOWAS) in 1975. ECOWAS was to act as an economic and a security platform for West Africa to cooperate so as to gain and enjoy selfdevelopment and settle disputes in a pacific way.

Nigeria-West African policy can also be understood against the background of regional security problem in the region. West Africa's security problems have been Nigeria's burden since independence. Nigeria considers African security problems, especially that of West Africa as germane to its foreign policy pursuits, which prompts Onwuka (2006) to describe security as a "scarce and sensitive commodity."

There is no doubt that the security demands of states interact, overlap or conflict in international relations, and states in the West African sub-regions are no exception. First it is evident that apart from the current security challenges from the Islamic extremists - Boko Haram, Nigeria is stabilising democratically and the government is working out measures to overcome this challenge. Second, all the identified problems facing Africa in general and West Africa in particular are well appreciated by successive Nigerian governments, particular from the 1970s to date, and these reflect in their foreign policy that has Africa as its centerpiece. In essays on "Nigerian Foreign Policy Governance and International Security", Adeniji (2000) highlights Nigeria's consistency in African security. The areas outlined include: Nigeria's role in the anti-apartheid movement in Southern Africa, liberation movements in Zimbabwe, Angola and Namibia, resolution of conflicts in Liberia and Sierra Leone, and Nigeria's politics of harmonisation through regional integration and security.

Other areas related to security include democracy, good governance, sustainable human development in Africa, disarmament and confidence building among African states and conventional weapons control measures. Adeniji however surmises that a new African agenda is needed in Nigeria's foreign policy because of the changes in the global system that affects the continent. For him, Africa must remain the primary focus of its foreign policy and with the reduction of the strategic and ideological interests of the major powers in the developing countries, regional peace and security issues as well as regional economic and social development will become essentially the task of countries in the region. "In an eventual multi-polar world, the role of regional powers will become more vital and Nigeria must seek to remain one of the major powers, if not the major power in Africa." (Adeniji, 2000: 21).

On Nigeria's emphatic leadership role in West Africa, Babangida, a one-time president of Nigeria, reasoned that "in a sub-region of where one out of three West Africans is a Nigeria, it is imperative that any regime in this country should relentlessly strive towards the prevention or avoidance of the deterioration of any crisis which threatens to jeopardise or compromise the stability, prosperity and security of the sub-region. It was this very objective that propelled our pioneering efforts in the establishment of ECOWAS and made inevitable our continuing strong commitment and support for the organisation." (Babangida, 1990: 13) The attitude of Babangida's government therefore was that whenever certain events occurred depending upon its intensity and magnitude, which may affect Nigeria, the country would not stand aloof. Nigeria's foreign policy on peaceful coexistence and secure neighbourhood is that Nigeria would act "in collaboration with others in the sub-region, to react or respond in appropriate manner necessary to either avert the disaster or to take adequate measures to ensure peace, tranquility and harmony." (Babangida, 1990c: 4).

It was against this background that Nigeria championed the establishment of ECOWAS through the Treaty of Lagos in May, 1975 in order to promote cooperation and development among the countries in the West African sub-region in all fields of economic activity, foster closer relations among the ECOWAS members and provide enabling political and physical security environment for economic activities to blossom. 


\subsection{NIGERIA AND REGIONAL SECURITY}

Nigeria has been pre-occupied with the tackling of Africa's security problems since her independence in 1960. This made her to consider regional security as germane to her foreign policy pursuit. Her strong engagement in regional security, especially in the area of armed intervention, is due to her quest to assert regional leadership in the West Africa sub-region. Haastrup and Lucia (2014) capture succinctly the reason behind Nigeria's active role in regional security. According to the duo:

If we take the regional security policy areas classified in Kirchner and Dominques (2011) "assurance," "prevention," and "compellance" as a point of departure for analyzing regional security governance, Nigeria through ECOWAS plays very active roles in these areas with the following aims: to launch regional actions in cases of conflict; to develop normative framework for regional security; and to promote conflict prevention measures. Nigeria is central here as it dominates ECOWAS in terms of providing human and material resources" (Haastrup and Lucia, 2014:6).

Thus, ECOWAS' achievements in regional security is made possible partly by Nigeria's immense contribution in men, money and materials.

Nigeria has also made immense contributions to regional security through mediation. Mediation has been a veritable and an old instrument of Nigeria's foreign policy since her independence. The security challenges in West Africa immediately after independence were essentially inter-state which revolve around border disputes. Nigeria has always played an interventionist role in conflict mediation and has maintained a lead in security matters in the West African sub-region within the framework of the ECOWAS Mediation and Security Council.

Having led other countries in West Africa to establish the Economic Community of West African States (ECOWAS) in 1975, Nigeria has since then taken the front seat in conflict resolutions in West Africa. The country has championed the resolution of many devastating conflicts that engulfed many countries in the sub-region. Nigerian was instrumental to the creation of ECOWAS Cease Fire Monitoring Group (ECOMOG) which facilitated the resolution of the Liberian and Sierra Leone conflicts and the restoration of democracy in both countries. Since its creation in 1990, ECOMOG has at various times been deployed to conflict areas as a regional peacekeeping and intervention force. The regional military body has often adopted multi-dimensional peacekeeping through monitoring implementation of peace agreements reached between warring parties as her conflict resolution mechanism. In addition to her leadership role in ECOWAS' efforts in conflict resolution in West Africa, Nigeria has also been instrumental in most of the conflict mediation diplomacy and peace settlement agreements in almost all the recent wars in the West African sub-region.

At very crucial moments in the history of ECOWAS' conflict management, conflict resolution, peacekeeping and peace building, Nigeria has always been available to provide funding and logistics (Akindele, 2003). In confirming Akindele's observation, Abubakar asserts that "over 70 percent of ECOMOG's troops and 80 percent of funds were provided by Nigeria" (Abubakar, 2009:195). ECOMOG was created in 1990 under Nigeria's initiative, initially to respond to the civil war in Liberia. It subsequently intervened in Sierra Leone, Cote d'Ivoire and other countries in West Africa that experienced one crisis or the other. All these interventions were under the leadership of Nigeria.

Alli (2012:23) observes that "one notable exception to Nigeria's contribution was her refusal to send troops as part of Guinea-Bissau mission, which ended up being a significant failure for the ECOMOG mission. This seems to demonstrate that Nigeria's participation is very important to the success of mission like this." Another striking observation made by Iwilade and Agbor (2012), shows that Nigeria takes advantage of the reluctance of the international community to intervene in crises and conflicts in Africa, especially where their interests are not threatened to assert her influence and leadership role in the West African sub-region. According to the duo, "Nigeria took advantage of the security vacuum left by the international community in the wake of the many conflicts in the immediate post-Cold War period to intervene in order to further its security and also assert its role as leader in this regional context" (Iwilade \& Agbor, 2002:364).

In examining Nigeria's role in regional security, scholars like Bello (2012) and Obada (2013) note that there is evidence of an established nexus between national and regional security. They argue that perceived national threats also have transnational or regional dimensions; conversely, sub-regional security is deemed as having a potential effect on national security and stability. Bello (2012:8) articulates this by citing Nigeria's national defense policy objectives as including the security and stability in the West African sub-region through collective security." Similarly, Obada (2013) defines regional security by way of combating terrorism and other transnational crimes as being of strategic interest to Nigeria. It is therefore, believed that Nigeria's security is tied to that of other states in the sub-region "because of cultural and historical experience, and because of transnational security 
issues which are defined by the way in which the security of a nation is affected by what happens in contiguous states" (Yorom, 2010 cited in Alli, 2012:13). Perhaps, it is on this basis that Ate argues that "Nigeria must treat this sub-region as a natural base from which to project its national interests and regional influence" (Ate, 2011:90).

From Alli's point of view, "the 1975 Adedeji report on the review of Nigeria's foreign policy led the country to adopt a policy platform that seeks to make the safeguarding of the territorial integrity of all African states a national policy objective and led in part to the idea of Africa as the centre-piece of the nation's foreign policy" (Alli, 2012:4). Alli observes further that Nigeria exhibits what Adebayo describes as "missionary zeal" in assuming the role of benevolent "older brother" responsible for protecting younger siblings, immediate neighbours, fellow Africans and black people.

Nigeria has exhibited leadership role in regional security through conflict resolution, conflict management, peacekeeping operations and mediation activities. The country is also at the forefront of democratic consolidation and support for economic development in West Africa. She offers strategic security training to the armed forces of many member states of the Economic Community of West African States (ECOWAS). Evidence shows that Nigeria has been able to play a defining role in regional security in West Africa through peacekeeping operations, conflict resolutions and mediation in West African States like Liberia (1990), Sierra Leone (1991), Guinea-Bissau (1998), Cote d'Ivoire (2002 and 2011) and Mali (2012).

The high point of Nigeria's security leadership role in the West African sub-region was her intervention in Liberia and Sierra Leone through peacekeeping and enforcement operations. It started with Nigeria's intervention in Liberia in 1990, when she led other ECOWAS states to establish the ECOWAS Monitoring Group (ECOMOG) for peacekeeping operations in Liberia.

After the war, Nigeria supervised the conduct of the general and presidential elections which saw the emergence of Charles Taylor as the Liberian president. The Liberian war generated ripple effects in the West African sub-region. According to Howe (1997:166), "besides constituting a threat to the security of the regional neighbourhood by the way of inspiring other local or civil conflicts, it had also led to the emergence of rebellious elements in other parts of the region." Howe notes that the worst hit was Liberia's neighbouring state, Sierra Leone whose domestic peace, according to him came to abrupt end with the outbreak of violence. The violence was as a result of insurgency led by Foday Sankoh against the Sierra Leone government. This rebellious group known as the Revolutionary United Front of Sierra Leone was literally backed by the Liberian government of Charles Taylor.

Nigeria led an interventionist force which compelled an immediate retreat of the insurgents from the center of power in Free Town to the sub-urban. The government of Ahmed Tejan Kabba was thus weekend by the activities of the Liberian-backed insurgents. The Sierra Leone government turned to Nigeria for security and defense of the country, with Nigeria's General Maxwell Khobe appointed by Tejan Kabbah as Sierra Leone Chief of Defense Staff (Kolawole, 2005). While effectively assisting the democratically elected government in Sierra Leone to get rid of the insurgents, Nigerian government continually committed funds, materials and human resources to ECOMOG's peacekeeping operations in Sierra Leone.

Nigeria's leadership role in regional security was unprecedented during the regime of General Sanni Abacha. It was during Abacha's regime that Nigeria, for the first time, practically changed the government of another country and took over the national defense and security of the country in fulfillment of her leadership role in regional security in West Africa. Fawole captures this milestone in Nigeria's African policy thrust by noting that:

The near unilateral and aggressive intervention by Nigeria introduced a decidedly novel dimension to Nigeria's sub-regional leadership. Not only did it succeed in forcefully unseating a defacto regime to support the newly civilian government in Freetown with troops and weapons, in a way Nigeria had single-handedly decided the fate of another country (Fawole, 2003:208).

In his work, Essays on Nigerian Foreign Policy Governance and International Security, Adeniji highlights Nigeria's consistency in African security. He outlined and examined Nigeria's role in the resolution conflicts and disputes, mediation and peacekeeping operations in the West African sub-region. Other areas related to security where Adenyi discussed Nigeria's leadership role include democracy, good governance, sustainable human development in the sub-region, disarmament and confidence-building among the states in the sub-region. Adeniji however, advocates a paradigm shift in Nigeria's African foreign policy if the country's leadership position in West Africa is to be consolidated, considering the changes that has taken place in the international system which affect Africa. Since there is a reduction of strategic and ideological interest of the major powers in the third world countries, Adeniji advises that regional peace and security issues should be the responsibility of countries in the region. He admonishes that Nigeria must seek to remain one of the major powers, if not the major power in Africa in an eventual multipolar international system, where the role of regional powers will be vital. 
Since its establishment in 1975, ECOWAS, under the leadership of Nigeria has been developing a permanent institutional and normative framework to address security challenges in West Africa. The country has contributed financially more than any other country in West Africa in the area of conflict resolution and peacekeeping operations in the sub-region. Bamali (2009) asserts that by 1999, it was estimated that Nigeria had spent over 13 billion US dollars in peacekeeping operations in the West African Sub-region. Bamali's assertion is in line with George's observation that "Nigeria spent on the ECOMOG operation about one million US dollars daily" (George, 2012:425).

Using the instrumentality of ECOWAS, Nigerian leaders have been participating actively more than any other country in West Africa in terms of mediation to resolve conflicts in the sub-region: "from the Lome peace Agreement which ended the Sierra Leone civil war in July 1999, to the 2005-2006 crisis in Togo, when two main leaders in the crisis - Faure Gnassingbe and the main opposition leader, Emmanuel Akitani were invited to Abuja to sign a peace accord" (Alli, 2012:53). Alli (2012) also admits that since independence, Nigerian leaders have played significant role in mediating in regional conflicts. He cites Nigeria's intervention in Liberia and Sierra Leone as a demonstration of his argument. Alli also acknowledged President Obasanjo's diplomatic efforts in conflict resolution in the West African sub-region. "President Obasanjo exemplified this personal diplomatic efforts and involvement in mediation, peace-making and conflict resolution. He played critical roles in all these mediation efforts. His shuttle diplomacy across West Africa led to the resolution of several conflicts and political crises, sometimes at night." (Alli, 2012:54). Sanda (2004) also acknowledged President Obasanjo's contribution to peace and security in West Africa. He observed that in 2003, President Obasanjo brokered a settlement between rebel soldiers and President Charles Taylor of Liberia which facilitated the establishment of the Government of National Unity in Liberia and provision of asylum for Charles Taylor in Nigeria.

\subsection{Critical Analysis of Nigeria's National Interest and Interventions in West African Conflicts}

Questions have been asked by Nigerians on Nigeria's involvement in the domestic conflicts of states in West Africa when there are numerous unresolved conflicts at home, including the Boko Haram insurgency in the Northern part of the country. These Nigerians have questioned the rationale behind Nigeria's commitment in men, money and materials in the resolution of conflicts in the West African sub-region at the expense of the country's development and welfare of her citizens.

Hassan (2008) argues that even though Nigeria's intervention in the conflict in Cote d'Ivoire and other states in West Africa is desirable, these interventions have cost Nigeria enormous financial and human resources. According to him, "the historic contributions of Nigeria to regional peace and security which has cost the country so much money, not to mention the gallant men and women of the Nigerian Armed Forces who paid the supreme sacrifice, are hardly acknowledged by the international community in general and the African continent in particular." (Al-Hassan, 2008:2).

Taking cognizance of these contributions made by Nigeria towards African peace, security and development, Eke (2009:138) raised one fundamental question: "Upon all the enviable roles and contributions which Nigeria made in the continent, can the nation continue to pursue African agenda at such monumental cost without visible tangible benefits to the country's national interest? In line with Eke's question, Al-Hassan (2008:3) observes that "Nigeria is making too much contributions in Africa without corresponding positive outcome." He believes that the centerpiece of any country's foreign policy ought to be that country itself if it seriously considers itself a rational actor in the international system. Every single action taken by Nigeria in Africa generally and West Africa particularly, according to him, must reflect Nigeria's national interest.

Although Nigeria is endowed with mineral resources which earns her enormous wealth with which she funds her involvement in African conflicts, the scale of such funding affects her domestic development and the welfare of her citizens negatively. The above scenario is graphically captured by Idumange (2011:2) who states that "Nigeria is characterized by mass poverty, grave insecurity, dilapidated economic and social infrastructure, which has triggered the forces of corruption, marginalization, ethnicity and prebendal politics."

Oyetunde (2002) agrees with the above scholars when he remarked that Nigeria's foreign policy is static, unprogressive, and it is not benevolent to a large segment of the Nigerian populace. Idumange (2011) advocates a more pragmatic approach to Nigeria's foreign policy that will promote her national interest. "While it may be asserted that Nigeria's national interest tends to promote the core values and objectives of her diplomacy in principle, there is an urgent need to forge a more pragmatic approach to issues rather than engage in populist and unrewarding ideological loyalty and nebulous diplomatic permutations" (Idumange, 2011:2).

There is a consensus among radical scholars whose works were reviewed above (Al-Hassan, 2008; Eke, 2009; and Idumange, 2011) that Nigeria's foreign policy is unprogressive and not beneficial to majority of Nigerians because of the inability of the leadership of the country to define what constitutes Nigeria's national interest. These scholars believe that, since foreign 
policy is an extension of domestic policy, Nigeria's domestic environment does not support her frequent interventions in African affairs that cost the country monumentally in terms of financial, material and human resources. They maintain that Nigeria exhibits false generosity outside the shores of Nigeria in order to create a wrong impression that the country's political economy is healthy. As a result of the inability of the country's leadership to define her national interest, her frequent involvement in conflicts in Africa, especially in West Africa at the expense of her domestic development and welfare of her citizens is viewed with mixed feeling by Nigerians.

Williams (2008) is one of those who believe that the associated widespread poverty, unemployment and insecurity in Nigeria are responsible for lack of public support for Nigeria's frequent interventions for peace and security in West Africa. He queries the rationale for Nigeria's frequent interventions to maintain peace and security in the sub-region when "Nigeria is enmeshed in insecurity going by cases of seeming intractable sectarian crises, particularly in its northern region. Yearly, there is outbreak of ethno-religious conflicts with tragic consequences fuelled by huge population of willing, hungry, desperate, unemployed youths seeking avenues for expressing discontentment over under-performing governments at every level." (Williams, 2008:309).

Lending his voice to this line of argument, Adebajo (2010) argues that Nigeria's foreign policy adventures vis-à-vis interventions in conflicts, especially in the West African sub-region, face strong opposition because of the failure of successive Nigerian governments to apply the principle of "Responsibility to Protect" domestically. He believes that the internal situation in Nigeria calls for greater attention as the country continues to suffer all manners of security challenges, ranging from widespread robbery to kidnapping, ethno-religious conflicts, and now terrorism (Boko Haram insurgency). This must have informed Soremekun's (1997:12) positions that "in a situation where a country's foreign vision and assumed roles impact negatively on its domestic affairs, its foreign objectives must be re-examined and refocused."

Soremekun's argument here is that, in the atmosphere of growing domestic instability and declining economy, Nigeria's frequent interventions to resolve conflicts in West Africa should be reviewed. How can Nigeria spend enormous resources in promoting peace and security in West Africa when both peace and security are absent at home?

From the economic perspective of Nigeria's national interest and interventions in the West African sub-region, the views of scholars like Williams (2008) and Idumange (2011) is that Nigeria's interventions in the sub-region cannot be justified. They argue that such interventions are not necessary because at the end of the conflict that warranted Nigeria's intervention, there seem to be no tangible national economic interest at stake, "unlike the gulf war of 1991 in which the Allied Coalition Forces fought to keep the oil lanes open to the Eastern and Western users." (Williams 2008:309) At the end of the conflict in which Nigeria committed a lot of financial and material resources, including men and women who lost their lives, neither the Nigerian government nor Nigerian business men benefited from such interventions. Using Sierra Leone as an example, Williams (2008) and Idumange (2011) note that at the end of the conflict, Lebanese and Indian businessmen flooded Freetown doing one business or the other instead of Nigerian businessmen, considering the fact that the resources that could have been used for Nigeria's domestic development was used for the resolution of the Sierra Leone conflict. Their views have been shared by many Nigerians who argue against Nigeria's frequent interventions in conflicts in West Africa. Agwu (2009:12-13) observes that:

Nigeria's foreign policy has witnessed enormous costs without any corresponding dividends. For instance, Nigeria has been a party to many peacekeeping operations at the sub-regional, continental and global levels with so many sacrifices, yet no explicit or implicit post-policy dividend has ever been derived from such military exertions. Policy analysts have resultantly not misjudged in their observation that Nigeria does not benefit maximally, anything near proportionately from United Nations peacekeeping funds or even jobs and positions.

Agwu further observes that when the United States of America and other Allied Coalition Forces invaded Iraq and overthrew Saddam Hussein, "American companies like Halliburton and the entire defence sector promptly revved up and readied themselves for the post-conflict reconstruction in that country. In the case of Nigeria in Liberia and Sierra Leone under ECOMOG, no such post-conflict reconstruction engagements ensued to the benefit of the Nigerian state, the private sector or any segment of the civil society". (Ibid)

Based on this fact, Bassey (2004:101) articulated Agwu's (2009) view more precisely when he captured the mood and verdict of many Nigerians:

The Nigerian military intervention in Liberia and Sierra Leone has been the most traumatic and economically wasteful experience in the forty-three years of independence. Against the background of collapsing industrial communication infrastructure, moribund health delivery 
system and educational institutions, widespread poverty, cascading debt burden and prostrate manufacturing sectors, many Nigerians have wondered and shouted aloud in the electronic and print media how we got into the cauldron of Liberia and Sierra Leone.

Obadiah, cited in Al-Hassan (2008:5) believes that "every single action shall be adjudged by how much it advances our national power and influence, and how much it advances our interest, objectives and purposes." These Nigerians have advanced their argument against Nigeria's intervention in African affairs after taking into consideration the enormous funds Nigeria spends in military interventions in Africa, especially in West Africa, while almost all the domestic sectors are yearning for attention, and above all the standard of living of many Nigerians is grossly inadequate.

In contrast to the views of Williams (2008) and Idumange (2011), whose arguments are based on just national economic interest, Akinyemi (1987) identifies the achievement of national security interest as one of the justifications for Nigeria's intervention in African conflicts, especially in the West African sub-region. He contends that Nigeria has always been at the forefront of conflict resolution in the West African sub-region in order to maintain peace and security in the sub-region. Akinyemi acknowledges that Nigeria's peace initiatives in West Africa are done on the belief that conflicts do have spillover effects which at times destabilizes other regions or states by promoting insecurity, poverty and political instability. He believes that Nigeria's conflict resolution initiative within West Africa is premised on the notion that Nigeria's security is inextricably tied to the security of West Africa.

\subsection{CONCLUSION}

Within the framework of ECOWAS and AU, Nigeria has taken a lead role in security matters in West Africa through interventions and diplomatic mediations in conflict situations in the sub-region. The country has exhibited this leadership role in maintaining regional security through conflict resolution, peacekeeping and mediation activities. There is no doubt therefore, that Nigeria has played a significant role in regional security in the West African sub-region. The climax of Nigeria's security leadership role in the West Africa was the peacekeeping and enforcement in Liberia, Sierra Leone and Cote d'Ivoire. The country pushed for the resolution of the devastating conflicts that engulfed these countries and other countries in the West African subregion.

Under the sub-regional hegemony of Nigeria, the ECOWAS Cease Fire Monitoring Group (ECOMOG) was established and deployed to some conflict zones as regional peacekeeping and intervention forces. Having championed the establishment of the Economic Community of West African States (ECOWAS) in 1975, Nigeria has remained at the forefront of conflict prevention and resolution in West Africa. In addition to her role in ECOWAS' efforts in resolving conflicts in West Africa, Nigeria has also been instrumental in most of the conflict mediation, diplomacy and peace settlement agreements in almost all the wars in the sub-region. The country's leaders, through the instrumentality of ECOWAS, have not been found wanting in conflict resolution and mediation in the West African sub-region.

In looking at Nigeria's role in regional security, there is evidence of an established nexus between national and regional security. Perceived or real national threats also have transnational or regional dimensions; conversely, sub-regional security is deemed as having a potential effect on national security and stability. This goes to show that Nigeria's security is tied to that of other states in the sub-region. With this in mind, there is no doubt that the security demands of states interact, and overlap.

\section{REFERENCES}

Abubakar, A. A. (2009). "Peacekeeping in West Africa: The Nigerian Experience", in G. J. Jonah and I. S. Zabadi (eds.) Peace Support Operations in the New Global Environment: The Nigerian Perspective, Abuja: National Defence College.

Adebajo, A. (2008). "Hegemony on a Shoestring: Nigeria's Post-Cold War Foreign Policy", in A. Adebajo and A. R. Mustapha (eds.) Gulliver's Troubles, South Africa: University of Kwa Zulu Natal Press.

Adeniji, O. (2000). Essays on Nigerian Foreign Policy Governance and International Security. Ibadan: Dokun Publishing House.

Agwu, F. A. (2009). National Interest, International Law and Our Shared Destiny. Ibadan: Spectrum Books Limited.

Akinbobola, A. (2000). Regionalism and Regional Influentials: The Post-Code War Role of Nigeria in African Affairs. Lagos: Concept Publications Ltd.

Akindele, R. A. (2003). "Foreign Policy in Federal Politics: A Case Study of Nigeria" in A. T. Gana, and S. G. Egwu (eds.) Federalism in Africa. Eritrea: African World Press Inc. 
Akinyemi, B. (1987). "Reciprocity in Nigerian Foreign Policy" (The Akinyemi Doctrine) Nigerian Forum, May-June. Nos. 5 and 6. pp1.

Al-Hassan, H. Y. (2008). Nigeria-Africa Foreign Policy: Time for Sober Reflection. Retrieved from http://www. economicconfidential.com/Agusfeatureshadi.htl (Accessed 21/01/14).

Ali, W. O. (2012). The Role of Nigeria in Regional Security Policy. Abuja: Friedrich-Ebert-Stifung. Available at http://library.fes.depdf-file/bueros/nigeria/09372.pdf. (Accesssed 15/10/14).

Bamali, N. (2009). Redefining Nigeria's Interest and Commitments in Peace Support Operations, in B. A. Akinterinwa (ed.) Nigeria's National Interests in a Globalising World: Further Reflections on Constructive and Beneficial Concentricism. Ibadan: Bolytag International Publishers.

Bassey, C. O. (2004). Book Review: The Reversed Victory: Story of Nigerian Military Intervention in Sierra Leone. Calabar Journal of Politics and Administration. Vol. 4, No. 2, pp. 23 - 40.

Bello, H. M. (2012). Ministerial Platform on the Activities, Programmes and Achievement of the Ministry of Defence. From May 2011 to May 2012.

Eke, O.A. (2009). Globalization Challenges and Nigerian Foreign Policy. Abakaliki: Willy Rose \& Appleseed Publishing Coy

Fawole W.A (2003). Nigerian Foreign Policy under Gowon. Ibadan: University Press

George, O. (2012). From Rookie to Mandarin: The Memoirs of Second Generation Diplomat, Ibadan: BIP

Howe, H. (1997). "Lessons and of Liberia: ECOMOG and Regional Peacekeeping”, International Security Vol. 21, pp. 145-176

Iwilade, A. \& Agbo, J. U. (2012). "ECOWAS and the Regulation of Regional Peace and Security in West Africa", Democracy and Security, Vol. 8, No. 4. pp. 358-373

King, M.C. (1996). Basic Currents of Nigeria Foreign Policy. Washington D.C.: Howard University Press

Kirchner, E. J. \& Dominguez, R. (2011). The Security Governance of Regional Organizations. London: New York: Routledge

Kolawole. D. (2005). "From Isolation to Globalization: Transformation of Nigeria's Foreign Policy from the Abacha Regime to Obasanjo's Administration" Pakistan Journal of Social Sciences, Vol. 3, No. 6, pp 873-879

Obada, E.O. (2013). Nigeria's Defence Priorities: Domestic Stability for Regional Security. Abuja: Chatham House

Shaw, T.M. (1987). "Nigeria Restrained: Foreign Policy under Changing Political and Petroleum Regimes", The Annals of the American Academy of Political and Social Sciences, Vol. 489, No. 1, pg. 40-50.

Williams, P. (2008). "Keeping the Peace in Africa: Why African Solutions are not Enough". Ethics and International Affairs, Vol. 22, No. 3, pp. 309-329. 